\title{
Intrauterine growth retardation-associated syncytin b hypermethylation in maternal rat blood revealed by DNA methylation array analysis
}

\author{
Dong-Mei Wu ${ }^{1}$, You-E. Yan ${ }^{1}$, Liang-Peng Ma ${ }^{2}$, Han-Xiao Liu ${ }^{1}$, Wen $\mathrm{Qu}^{1}$ and Jie Ping ${ }^{1}$
}

BACKGROUND: Emerging evidence suggests that DNA methylation in maternal blood is a promising target for intrauterine growth retardation (IUGR) screening, a common developmental toxicity. Here, we aimed to screen out IUGRrelated DNA methylation status in maternal blood via highthroughput profiling.

METHODS: Pregnant Wistar rats were subcutaneously administered nicotine $(1 \mathrm{mg} / \mathrm{kg})$ twice per day from gestational day (GD) 11 to GD20 to establish the IUGR model. MeDIP array assays and the following $\mathrm{GO}$ analysis were used to evaluate DNA methylation status in maternal blood. One placental development-associated gene was selected for further confirmation.

RESULTS: Genes regulating the development of multiple organs and major body systems had changed DNA methylation frequencies in the maternal blood of IUGR rats. Placental development, which can affect the development of multiple fetal organs and induce IUGR, is a hypermethylated cluster consisting of four significantly changed genes, including syncytin b (Synb), Lrrc15, Met, and Tex19.1. With the most significant change, Synb hypermethylation in maternal blood was confirmed by bisulfite-sequencing PCR (BSP). Moreover, decreased Synb expression and histological changes were observed in IUGR placentae.

CONCLUSION: The IUGR-associated DNA methylation profile in maternal blood, such as placenta-related Synb hypermethylation, provides evidence for further studies on possible IUGR biomarkers.

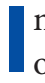
ntrauterine growth retardation (IUGR) is a common obstetrics complication, and is defined as a birthweight and/or length below the 10th percentile for the corresponding gestational age and an abdominal circumference that is less than the 2.5th percentile, with pathologic restriction of fetal growth (1). The prevalence of IUGR is about $8 \%$ worldwide (2). Increasing evidence supports that IUGR is related to increased prenatal morbidity and a higher susceptibility to some adult diseases in the offspring, such as the metabolic syndrome (3).

The etiology of IUGR is largely attributed to the adverse intrauterine environment during pregnancy. It is widely reported that maternal exposure to certain exogenous factors, such as maternal undernutrition and smoking, can inhibit fetal development by affecting the expression of developmental genes $(4,5)$. Epigenetics, which regulates the gene expression without changing the gene sequence, explains the relationship between gene expression and environmental signals (6). DNA methylation is a major epigenetic mechanism that can affect the stable maintenance of gene expression patterns (7). Reamon-Buettner et al. (8) observed that gestational protein deficiency could induce site-specific hypomethylation of the Wnt2 promoter region in the placenta and cause IUGR in rats. In our previous study, increased DNA methylation and decreased expression levels of several developmental genes (e.g., steroidogenic factor-1 and scavenger receptor class B type I) were observed in adrenals of IUGR fetal rats under prenatal caffeine ingestion $(9,10)$. Therefore, aberrant DNA methylation of developmental genes could be the underlying epigenetic mechanism for adverse intrauterine environment-induced IUGR.

Besides regulating gene expression in tissues and organs, DNA methylation status stably exists in body fluids $(3,7)$. As one of the readily available body fluids, maternal blood provides an avenue for signal exchange between the fetus and the mother (11). Thus, DNA methylation analysis in maternal peripheral blood may contribute to prenatal diagnosis or risk prediction, which has been proved in noninvasive prenatal diagnosis of trisomy 21 and congenital heart defects $(12,13)$. For IUGR, Kim et al. (14) first observed increased DNA methylation frequency of fetal-derived RASSF1A in maternal plasma of IUGR cases. However, no reports have focused on using high-throughput profiling of genomic DNA methylation in maternal blood to screen out IUGR.

In this study, we aimed to search for IUGR-related DNA methylation status in maternal peripheral blood. MeDIP array analysis was used to search for differentially methylated genes

\footnotetext{
'Department of Pharmacology, Wuhan University School of Basic Medical Sciences, Wuhan, Huibei, China; ${ }^{2}$ Department of Pharmacy, Wuhan First Hospital, Wuhan, Hubei, China. Correspondence: Jie Ping (pingjie@whu.edu.cn)

The first two authors contributed equally to this work.

Received 1 October 2016; accepted 28 May 2017; advance online publication 5 July 2017. doi:10.1038/pr.2017.137
} 


\section{DNA methylation in IUGR maternal blood 1 Articles}

in the maternal blood of a nicotine-induced IUGR rat model. On the basis of the results of GO analysis, one placenta-associated gene was selected for bisulfite-sequencing PCR (BSP) confirmation in maternal blood. The role of the selected gene in IUGR was confirmed in the placentae. This study will provide evidence for the non-invasive prenatal screening of IUGR and for exploring the possible epigenetic mechanism of IUGR.

\section{METHODS}

\section{Chemicals and Reagents}

Nicotine was obtained from Sigma-Aldrich (St Louis, MO). Isoflurane was purchased from Baxter Healthcare (Deerfield, IL). The DNeasy Blood \& Tissue Kit was provided by Qiagen (Hilden, Germany). The pGEM-T Easy vector was from Promega (Madison, WI). The EZ DNA methylation kit (No. D5006) was provided by Zymo Research (Orange, CA). The Trizol reagent was purchased from Invitrogen (Carlsbad, CA). The primers were synthesized by Sangon Biotech (Shanghai, China). All chemicals and reagents were of analytical grade.

\section{Animals and Treatment}

Specific pathogen-free Wistar rats (20 females weighing 180-220 g vs. 10 males weighing 260-300 g) were obtained from the Experimental Center of Hubei Medical Scientific Academy (No. 2008-0005, Hubei, China). The animal studies were performed at the Center for Animal Experimentation of Wuhan University (Wuhan, Hubei, P.R. China), which has been accredited by the Association for the Assessment and Accreditation of Laboratory Animal Care International (AAALAC International). The study protocol was designed in accordance with the Guidelines for Animal Research and was approved by the Ethical and Research Committee of the Medical College of Wuhan University.

The animals were housed under standard conditions and allowed free access to standard chow and water. They were allowed to acclimatize for at least one week before being subjected to experimental conditions. Each male rat was mated with two female rats, and the occurrence date of the vaginal plug or sperm in the vaginal smear was considered as gestational day (GD) 0 . The pregnant rats were randomly assigned to two groups. The pregnant rats in the nicotine group were subcutaneously administered nicotine $(1 \mathrm{mg} / \mathrm{kg}$ ) twice per day from GD11 to GD20, and the control group was administered the same volume of vehicle (saline). On GD20, the pregnant rats were anesthetized with isoflurane and killed by decapitation. The maternal blood was collected in sodium citrate tubes. Each feto-placental unit was quickly removed from the uterus. The number of pregnant rats in each group was set to 8 (the litter size of each pregnant rat was 8-14). The fetuses were weighed after being dried on filter paper. Three placentae from each group were randomly selected for fixing in $10 \%$ neutral formalin solution for $24 \mathrm{~h}$ to prepare paraffin slices. The remaining placentae were stored at $-80^{\circ} \mathrm{C}$. The IUGR rate was calculated according to the previously reported criteria for IUGR (4). All blood samples were stored at $4{ }^{\circ} \mathrm{C}$ and were subjected to genomic DNA extraction within 1 week.

\section{Genomic DNA Extraction and MeDIP Array Analysis}

Genomic DNA was extracted from maternal blood using the DNeasy Blood \& Tissue kit according to the manufacturer's protocol. Three samples from each group were selected randomly for DNA methylation array assays in KangChen Bio-tech (Shanghai, China). Rat DNA Methylation 385k CpG Plus Promoter Array from Roche NimbleGen (Madison, WI) was used to determine DNA methylation patterns in maternal blood. The $t$ test was performed between the two groups to calculate the $P$ values for each probe. Probes with $P$ values $<0.05$ were taken as differentially methylated probes, which were further analyzed to identify the differentially methylated region (DMR)-associated genes. GO analysis was applied to determine the roles of these DMR-associated genes and to screen out developmental genes needed subsequent confirmation.

\section{BSP Analysis of Syncytin b (Synb) in Maternal Blood}

The methylation status of the Synb promoter was determined by the BSP method. Genomic DNA in maternal blood (3 control vs. 3 nicotine) was isolated with a DNeasy Blood \& Tissue kit and then subjected to bisulfite modification using the EZ DNA methylation kit. The instruction manual of the EZ DNA methylation kit demonstrated that $500 \mathrm{pg}-2 \mu \mathrm{g}$ of DNA samples can be input in each reaction, and the bisulfite conversion efficiency could become higher than $99 \%$ under the optimal amount of DNA input, which is $200 \mathrm{ng}-500 \mathrm{ng}$. Thus, we input $500 \mathrm{ng}$ genomic DNA for every bisulfite conversion. The bisulfite-treated genomic DNA was amplified by PCR using the Thermal Cycler from Applied Biosystems (Foster City, CA). PCR products were electrophoretically separated and purified. The products were cloned into the pGEM-T easy vector for Sanger sequencing. Five clones were sequenced for each DNA sample. The percentage of methylation was calculated from the number of methylated $\mathrm{CpG}$ divided by the total $\mathrm{CpG}$ loci.

For PCR amplification, we used two pairs of primers (Synb-1 and Synb-2) covering almost the entire CpG-rich region of the proximal Synb promoter. The primers were designed by Methyl Primer Express 1.0 from Applied Biosystems. The primer sequences of Synb-1 (-325 bp $34 \mathrm{bp}$ ) were as follows: forward, $5^{\prime}$-TTTTGGGAA GGGATTTTTTTA-3'; and reverse, 5'-AAAAAACAAAACAA AAAACCCA-3'. Primers of Synb-2 (28 bp 422 bp) were as follows: forward, 5'-TATTTTTGGGTTTTTTGTTTTG-3'; and reverse, 5'-TCCTTCTCAAAATATATCACAAAA-3'. The reaction mixture contained $5 \mu \mathrm{l}$ of $10 \times$ PCR Buffer, $5 \mu \mathrm{l}$ of genomic DNA template, $4 \mu \mathrm{l}$ of $2.5 \mathrm{~mm}$ dNTPs, $1 \mu \mathrm{l}$ of $10 \mu \mathrm{M}$ of each primer, $0.5 \mu \mathrm{l}$ of $5 \mathrm{U} / \mu \mathrm{l}$ Taq HS, and $34.5 \mu \mathrm{l}$ of DEPC- $\mathrm{H}_{2} \mathrm{O}$. The amplification conditions were as follows: initial denaturation at $98{ }^{\circ} \mathrm{C}$ for $2 \mathrm{~min}$; 45 cycles of denaturation at $95^{\circ} \mathrm{C}$ for $30 \mathrm{~s}$, annealing at $61^{\circ} \mathrm{C}\left(\right.$ Synb-1) or $59^{\circ} \mathrm{C}$ (Synb-2) for $30 \mathrm{~s}$, and extension at $72^{\circ} \mathrm{C}$ for $30 \mathrm{~s}$; and a final elongation step at $72{ }^{\circ} \mathrm{C}$ for $10 \mathrm{~min}$.

\section{Hematoxylin and Eosin Staining in Placentae}

For histopathological measurement, neutral formalin-fixed placentae were processed into 5 - $\mu$ m-thick paraffin sections using standard histological techniques. Sections were stained with hematoxylin and eosin (HE) and were observed under a light microscope.

\section{RNA Extraction and Real-Time Reverse-Transcription PCR in Placentae}

Total RNA was isolated from the placentae using Trizol reagent by following the manufacturer's protocol. Detailed protocols for reversetranscription, primer design, and PCR condition have been published in our previous study (9). The mRNA content of Synb in each sample was normalized by the mRNA content of
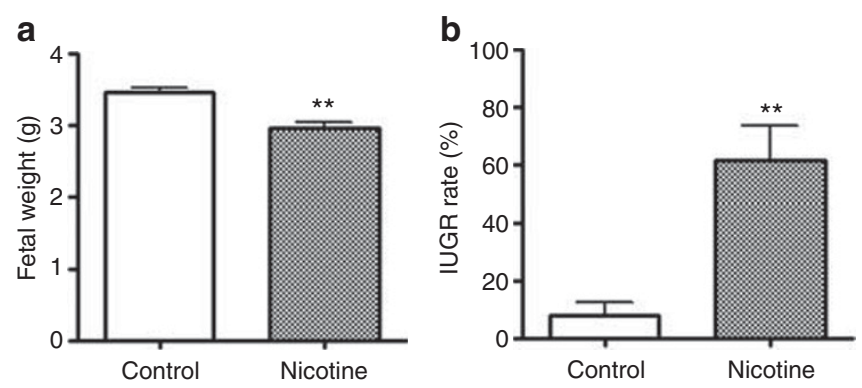

Figure 1. Effects of prenatal nicotine exposure on fetal weights and intrauterine growth retardation (IUGR) rates in rats on gestational day 20. (a) Fetal weights; (b) IUGR rates. Mean $\pm S D, n=8$ pregnant rats, ${ }^{* *} P<0.01$ vs. control. 


\section{Articles | wu et al.}

Table 1. Hypermethylated gene clusters related to fetal development in maternal peripheral blood on $\mathrm{GO}$ analysis

\begin{tabular}{|c|c|c|c|c|}
\hline $\mathrm{GO} I D^{\mathrm{a}}$ & Term $^{\mathrm{b}}$ & Count $^{c}$ & $P$ value $^{d}$ & $\mathrm{FDR}^{\mathrm{e}}$ \\
\hline \multicolumn{5}{|c|}{ Digestive system development } \\
\hline GO:0048565 & Digestive tract development & 24 & 0.001 & 0.010 \\
\hline \multicolumn{5}{|c|}{ Endoderm development } \\
\hline GO:0007492 & Endoderm development & 13 & 0.003 & 0.021 \\
\hline GO:0001706 & Endoderm formation & 6 & 0.028 & 0.113 \\
\hline \multicolumn{5}{|c|}{ Epidermis development } \\
\hline GO:0008544 & Epidermis development & 31 & 0.039 & 0.144 \\
\hline GO:0002064 & Epithelial cell development & 15 & 0.021 & 0.092 \\
\hline
\end{tabular}

Heart development

$\begin{array}{lllrr}\text { GO:0007507 } & \text { Heart development } & 80 & <0.001 & <0.001 \\ \text { GO:0003007 } & \text { Heart morphogenesis } & 33 & <0.001 & 0.003\end{array}$

Immune system development

$\begin{array}{llcrl}\text { GO:0002520 } & \begin{array}{l}\text { Immune system } \\ \text { development }\end{array} & 84 & <0.001 & 0.006 \\ \text { GO:0048536 } & \text { Spleen development } & 7 & 0.007 & 0.041 \\ \text { GO:0048538 } & \text { Thymus development } & 8 & 0.026 & 0.108\end{array}$

Leukocyte development

$\begin{array}{lllll}\text { GO:0002521 } \quad \text { Leukocyte differentiation } & 53 \quad 0.001 & 0.008\end{array}$

Limb development

G0:0021761

Limbic system development

16

0.016

0.074

Liver development

GO:0001889

Liver development

$27 \quad<0.001$

0.003

Mesoderm development

$\begin{array}{lllll}\text { GO:0007498 } & \text { Mesoderm development } & 29 & <0.001 & <0.001 \\ \text { GO:0001707 } & \text { Mesoderm formation } & 17 & <0.001 & <0.001 \\ \text { GO:0048332 } & \text { Mesoderm morphogenesis } & 20 & <0.001 & <0.001\end{array}$

Muscle development

$\begin{array}{lllll}\text { GO:0055001 } & \text { Muscle cell development } & 25 & 0.011 & 0.058 \\ \text { GO:0007517 } & \text { Muscle organ development } & 50 & 0.001 & 0.011 \\ \text { GO:0061061 } & \begin{array}{l}\text { Muscle structure } \\ \text { development }\end{array} & 71 & <0.001 & 0.001 \\ & \begin{array}{l}\text { Muscle tissue development } \\ \text { GO:0060537 }\end{array} & 49 & 0.004 & 0.026 \\ \text { GO:0014706 } & \text { Striated muscle tissue } & 46 & 0.007 & 0.041\end{array}$

Neurodevelopment

GO:0030900

$58<0.001<0.001$
Table 1 Continued

\begin{tabular}{|c|c|c|c|c|}
\hline $\mathrm{GO} I D^{\mathrm{a}}$ & Term $^{b}$ & Count $^{\mathrm{c}}$ & $P$ value ${ }^{d}$ & $\mathrm{FDR}^{\mathrm{e}}$ \\
\hline GO:0021766 & Hippocampus development & 13 & 0.014 & 0.066 \\
\hline GO:0001841 & Neural tube formation & 27 & $<0.001$ & $<0.001$ \\
\hline GO:0014020 & $\begin{array}{l}\text { Primary neural tube } \\
\text { formation }\end{array}$ & 24 & $<0.001$ & $<0.001$ \\
\hline GO:0021510 & Spinal cord development & 20 & 0.001 & 0.008 \\
\hline \multicolumn{5}{|c|}{ Placental development } \\
\hline GO:0001890 & Placental development & 4 & 0.048 & 0.1690 \\
\hline \multicolumn{5}{|c|}{ Respiratory system development } \\
\hline GO:0060541 & $\begin{array}{l}\text { Respiratory system } \\
\text { development }\end{array}$ & 31 & 0.041 & 0.150 \\
\hline
\end{tabular}

Sensory system development

\begin{tabular}{|c|c|c|c|c|}
\hline GO:0090102 & Cochlea development & 9 & 0.011 & 0.055 \\
\hline GO:0043583 & Ear development & 37 & $<0.001$ & 0.006 \\
\hline GO:0048839 & Inner ear development & 30 & 0.009 & 0.049 \\
\hline GO:0002088 & $\begin{array}{l}\text { Lens development in } \\
\text { camera-type eye }\end{array}$ & 11 & 0.038 & 0.141 \\
\hline GO:0007423 & $\begin{array}{l}\text { Sensory organ } \\
\text { development }\end{array}$ & 86 & $<0.001$ & $<0.001$ \\
\hline GO:0043586 & Tongue development & 6 & 0.028 & 0.1 \\
\hline
\end{tabular}

Skeletal development

$\begin{array}{llrrr}\text { GO:0060348 } & \text { Bone development } & 18 & 0.012 & 0.061 \\ \text { GO:0001501 } & \begin{array}{l}\text { Skeletal system } \\ \text { development }\end{array} & 63 & <0.001 & <0.001\end{array}$

Urogenital system development

$\begin{array}{lllrr}\text { GO:0008406 } & \text { Gonad development } & 34 & 0.013 & 0.062 \\ \text { GO:0001822 } & \text { Kidney development } & 43 & <0.001 & <0.001 \\ \text { GO:0008584 } & \text { Male gonad development } & 20 & 0.022 & 0.095 \\ \text { GO:0001541 } & \text { Ovarian follicle development } & 14 & 0.009 & 0.047 \\ \text { GO:0072001 } & \text { Renal system development } & 43 & <0.001 & <0.001 \\ \text { GO:0001657 } & \text { Ureteric bud development } & 24 & <0.001 & <0.001 \\ \text { GO:0001655 } & \text { Urogenital system } & 57 & <0.001 & <0.001 \\ & \text { development } & & & \end{array}$

Vascular system development

\begin{tabular}{|c|c|c|c|c|}
\hline GO:0001525 & Angiogenesis & 5 & 0.001 & 0.006 \\
\hline GO:0001568 & $\begin{array}{l}\text { Blood vessel } \\
\text { development }\end{array}$ & 6 & 0.001 & 0.006 \\
\hline GO:0001944 & $\begin{array}{l}\text { Vasculature } \\
\text { development }\end{array}$ & 85 & $<0.001$ & $<0.001$ \\
\hline GO:0001570 & Vasculogenesis & 17 & 0.001 & 0.006 \\
\hline \multicolumn{5}{|c|}{ 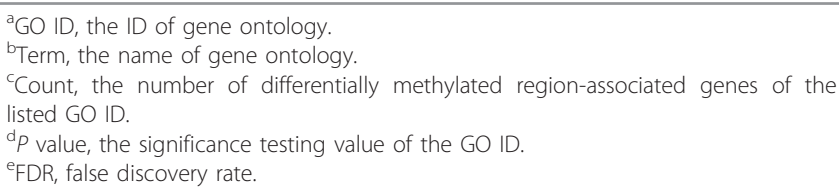 } \\
\hline
\end{tabular}


glyceraldehyde phosphate dehydrogenase (GAPDH). Primers for Synb (annealing at $60^{\circ} \mathrm{C}$ ) are as follows: forward primer, $5^{\prime}$-TCTG GGGACCACTCTTTACTG-3'; and reverse primer, 5'-GGGCTT TGAGAAGATTAGGG-3'. Primers for GAPDH (annealing at $60^{\circ} \mathrm{C}$ ) are as follows: forward primer, 5'-GCAAGTTCAACGGCACAG-3'; and reverse primer, 5'-GCCAGTAGACTCCACGACA-3'.

\section{Statistical Analysis}

SPSS 15.0 from SPSS Science Inc. (Chicago, IL) and Graphpad Prism 5.0 from GraphPad Software (La Jolla, CA) were used for data analysis. All measurement data were expressed as mean $\pm S D$ and evaluated with Student's $t$-test. Enumeration data, such as IUGR rates, were first calculated and then arcsine square-root transformed to make the data following normal distribution. The methylation frequencies of the two groups were compared statistically by Pearson's $\chi^{2}$ test (15). Statistical significance was set at $P<0.05$.

\section{RESULTS}

\section{Developmental Parameters}

As an important index for diagnosing IUGR, the fetal body weight significantly decreased in the nicotine group $(P<0.01$, Figure 1a) (16), and the nicotine group showed a higher IUGR rate compared with the control $(P<0.01$, Figure $\mathbf{1 b})$. Thus, the nicotine-induced IUGR rat model was established successfully in this study.

\section{MeDIP Array Analysis in Maternal Peripheral Blood}

Genomic DNA was extracted from whole-blood samples and was analyzed by MeDIP array assays. Generally, there were 2,269 hypermethylated DMR-associated genes and 2,092 hypomethylated DMR-associated genes in the nicotine group. The hypermethylated and hypomethylated clusters related to fetal development, as per the GO analysis, are listed in Tables 1 and 2, respectively. Eight of the listed clusters contained both hypermethylated and hypomethylated genes, including epidermis development, limb development, muscle development, neurodevelopment, respiratory system development, sensory system development, skeletal development, and urogenital system development. Hypermethylated genes also demonstrated in clusters about digestive system development, endoderm development, heart development, immune system development, leukocyte development, liver development, mesoderm development, placental development, and vascular system development.

\section{Aberrant Methylated Genes Related to Placental Development in Maternal Peripheral Blood}

We searched for fetal development-related aberrant methylated genes among the clusters listed in Tables 1 and 2 . The placenta serves as an essential barrier for fetal development, and placental dysfunction is taken as one of the predominant causes of IUGR. Thus, we analyzed genes related to placental development to screen out the gene for further analysis. There were four hypermethylated genes regulating placental development in the nicotine group (Table 3 ). The DNA methylation status of Synb demonstrated the most significantly change in this cluster.
Table 2. Hypomethylated gene clusters related to fetal development in maternal peripheral blood on GO analysis

\begin{tabular}{|c|c|c|c|c|}
\hline $\mathrm{GO} I \mathrm{ID}^{\mathrm{a}}$ & Term $^{\mathrm{b}}$ & Count $^{c}$ & $P$ value $^{\mathrm{d}}$ & $\mathrm{FDR}^{\mathrm{e}}$ \\
\hline \multicolumn{5}{|c|}{ Epidermis development } \\
\hline GO:0008544 & Epidermis development & 31 & 0.010 & 0.131 \\
\hline \multicolumn{5}{|c|}{ Limb development } \\
\hline GO:0021761 & $\begin{array}{l}\text { Limbic system } \\
\text { development }\end{array}$ & 14 & 0.029 & 0.232 \\
\hline
\end{tabular}

Muscle development

\begin{tabular}{|c|c|c|c|c|}
\hline GO:0055001 & Muscle cell development & 24 & 0.006 & 0.096 \\
\hline GO:0061061 & $\begin{array}{l}\text { Muscle structure } \\
\text { development }\end{array}$ & 60 & 0.001 & 0.042 \\
\hline GO:0060537 & $\begin{array}{l}\text { Muscle tissue } \\
\text { development }\end{array}$ & 47 & 0.001 & 0.041 \\
\hline GO:0014706 & $\begin{array}{l}\text { Striated muscle tissue } \\
\text { development }\end{array}$ & 47 & $<0.001$ & 0.022 \\
\hline
\end{tabular}

Neurodevelopment

$\begin{array}{llrrr}\text { GO:0030900 } & \text { Forebrain development } & 43 & 0.016 & 0.170 \\ \text { GO:0021766 } & \begin{array}{l}\text { Hippocampus } \\ \text { development }\end{array} & 12 & 0.015 & 0.160 \\ \text { GO:0048666 } & \text { Neuron development } & 82 & 0.011 & 0.135\end{array}$

Respiratory system development

$\begin{array}{lllll}\text { GO:0030324 } & \text { Lung development } & 26 & 0.032 & 0.244 \\ \text { GO:0030323 } & \text { Respiratory tube } & 26 & 0.036 & 0.262\end{array}$

Sensory system development

$\begin{array}{lllll}\text { GO:0043583 } & \text { Ear development } & 31 & 0.006 & 0.094 \\ \text { GO:0048839 } & \text { Inner ear development } & 29 & 0.004 & 0.079 \\ \text { GO:0002088 } & \begin{array}{l}\text { Lens development in } \\ \text { camera-type eye }\end{array} & 11 & 0.019 & 0.182 \\ \text { GO:0007423 } & \begin{array}{l}\text { Sensory organ } \\ \text { development }\end{array} & 60 & 0.017 & 0.175\end{array}$

Skeletal development

$\begin{array}{lllll}\text { GO:0060348 } & \text { Bone development } & 15 & 0.040 & 0.274 \\ \text { GO:0001501 } & \begin{array}{l}\text { Skeletal system } \\ \text { development }\end{array} & 45 & 0.020 & 0.195\end{array}$

Urogenital system development

\begin{tabular}{llcrl} 
GO:0072073 & $\begin{array}{l}\text { Kidney epithelium } \\
\text { development }\end{array}$ & 10 & 0.035 & 0.254 \\
GO:0072001 & $\begin{array}{l}\text { Renal system } \\
\text { development }\end{array}$ & 43 & $<0.001$ & 0.032 \\
GO:0003014 & Renal system process & 15 & 0.003 & 0.070 \\
\hline
\end{tabular}

${ }^{a} \mathrm{GO} I D$, the ID of gene ontology.

${ }^{\mathrm{b}}$ Term, the name of gene ontology.

cCount, the number of differentially methylated region-associated genes of the listed GO ID.

${ }^{d} P$ value, the significance testing value of the GO ID.

${ }^{\mathrm{e} F D R}$, false discovery rate. 


\section{Articles | Wu et al.}

\section{DNA Methylation Status of Synb Promoter in Maternal Peripheral Blood}

BSP analysis was employed to validate the DNA methylation status of Synb in maternal peripheral blood. Figure 2a demonstrated the total methylation map of the CpG-rich regions $(-325 \mathrm{bp} \sim 422 \mathrm{bp})$ of the rat Synb promoter in the two groups. As shown in Figure $2 \mathbf{b}$, the total methylation rate of the Synb promoter in the nicotine group was significantly higher than that of the control $(P<0.05)$. Among the $14 \mathrm{CpG}$ sites, nt -52 and 160 showed increased frequency of single CpG methylation after nicotine treatment $(P<0.05)$.

\section{Histopathological Changes and Synb Expression in Placentae}

Changes in placental structure were examined by HE staining. Syncytiotrophoblast hyperplasia and larger formation of syncytial knots were observed in the villous stroma of nicotine-treated placentae (Figure $3 \mathbf{c}, \mathbf{d}$ ), which were not evident in the control (Figure 3a,b). To confirm the role of Synb in placentae in our model, Synb expression was verified by real-time real-time reverse-transcription PCR in placentae. As shown in Figure 3e, prenatal nicotine exposure significantly reduced the Synb mRNA level to $64.9 \%$ of the control $(P<0.01)$.

Table 3. Differentially methylated region (DMR)-associated genes involved in placental development

\begin{tabular}{llc}
\hline Gene name & Description & $\begin{array}{c}\text { Peak score }^{\mathrm{a}} \times \text { Peak } \\
M \text { value }^{\mathrm{b}}\end{array}$ \\
\hline Synb & Syncytin b. Gene ID: 290348. & 13.00 \\
Lrrc15 & $\begin{array}{l}\text { Leucine-rich repeat containing } \\
\text { 15. Gene ID: 246296. }\end{array}$ & 11.44 \\
Met & $\begin{array}{l}\text { MET proto-oncogene, receptor } \\
\text { tyrosine kinase. Gene ID: 24553. }\end{array}$ & 11.02 \\
Tex19.1 & $\begin{array}{l}\text { Testis expressed 19.1. Gene ID: } \\
\text { 498033. }\end{array}$ & 10.26 \\
\hline
\end{tabular}

apeak score reflects the probability of positive enrichment.

${ }^{b}$ Peak $M$ value reflects the methylation level of the region.

\section{DISCUSSION}

Establishment of Nicotine-Induced IUGR Rat Model

Maternal cigarette smoking is a common risk factor for IUGR, although $\sim 20 \%$ of women continue smoking during pregnancy $(17,18)$. As one of the most aversive smoking products, nicotine can disturb fetal development and cause IUGR $(18,19)$. Both epidemiological investigations and animal experiments showed the association between prenatal nicotine exposure and increased IUGR rates $(20,21)$. Thus, prenatal nicotine exposure-induced IUGR is a recognized model and is widely used in IUGR-associated research. Usually, a period of 1-2 weeks is needed to establish a stable IUGR rat model through prenatal nicotine exposure (18). In this study, we referred to our previous studies and chose $1 \mathrm{mg} / \mathrm{kg}$ of nicotine exposure twice a day during GD11-GD20 to establish a typical IUGR rat model (4). Decreased fetal weights and increased IUGR rates were demonstrated in the nicotine group. It identified that the IUGR rat model was established successfully through prenatal nicotine exposure.

\section{Analysis of Changed DNA Methylation in Maternal Blood}

Early diagnosis and treatment is the goal of IUGR management (22). However, there is no definitively optimal method for screening and diagnosing IUGR during pregnancy. For example, ultrasound and Doppler flow, which require integration of multiple parameters and operator experience to identify IUGR, may fail to differentiate healthy but constitutionally small fetuses from IUGR, especially during the first trimester $(11,23)$. As a rapid, sensitive, and accurate method for IUGR screening, blood draw for nucleic acid analysis is characteristic of small cut, few complications, and tolerable pain, and can be regarded as a noninvasive method compared with amniocentesis (24). Meanwhile, placental and fetal nucleic acids can be detected in maternal blood from early pregnancy $(22,24)$. Therefore, measuring nucleic acids in maternal blood could also give us a better understanding of IUGR pathophysiology and underline the promise of DNA methylation status in maternal peripheral blood for IUGR screening. DNA methylation, a major
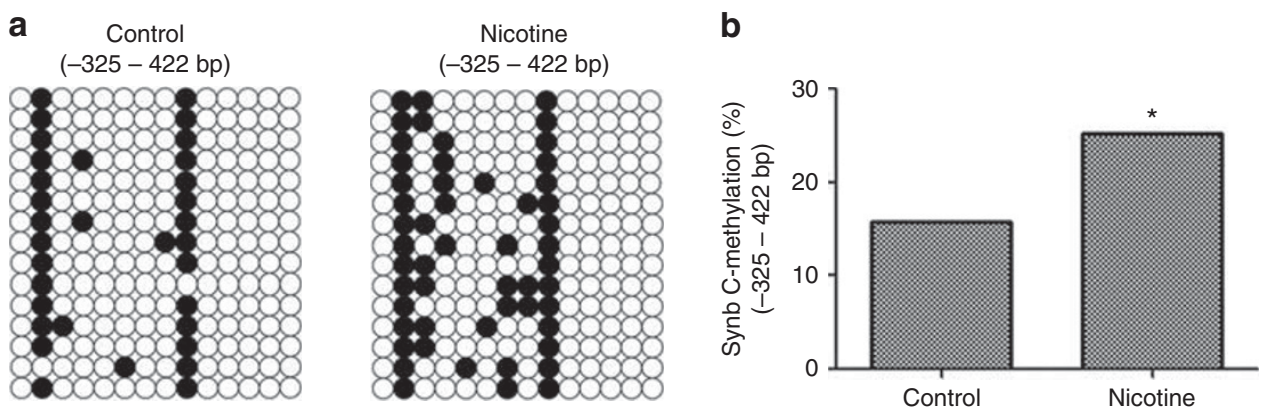

Figure 2. DNA methylation status of syncytin b (Synb) proximal promoter in maternal peripheral blood. The methylation rate of $\mathrm{CpG}$-rich regions ( -325 to 422 bp) within the human Synb proximal promoter was detected by bisulfite-sequencing PCR (BSP). (a) The total methylation map of the human Synb proximal promoter. Black and white circles represent methylated and unmethylated CpGs, respectively. Each horizontal row of circles represents $14 \mathrm{CpG}$ sites. (b) The total methylation rate of $\mathrm{CpG}$-rich regions within the proximal promoter of the Synb gene. The results were evaluated with Pearson' $X^{2}$ test. $n=3$ pregnant rats, ${ }^{*} P<0.05$ vs. control. 

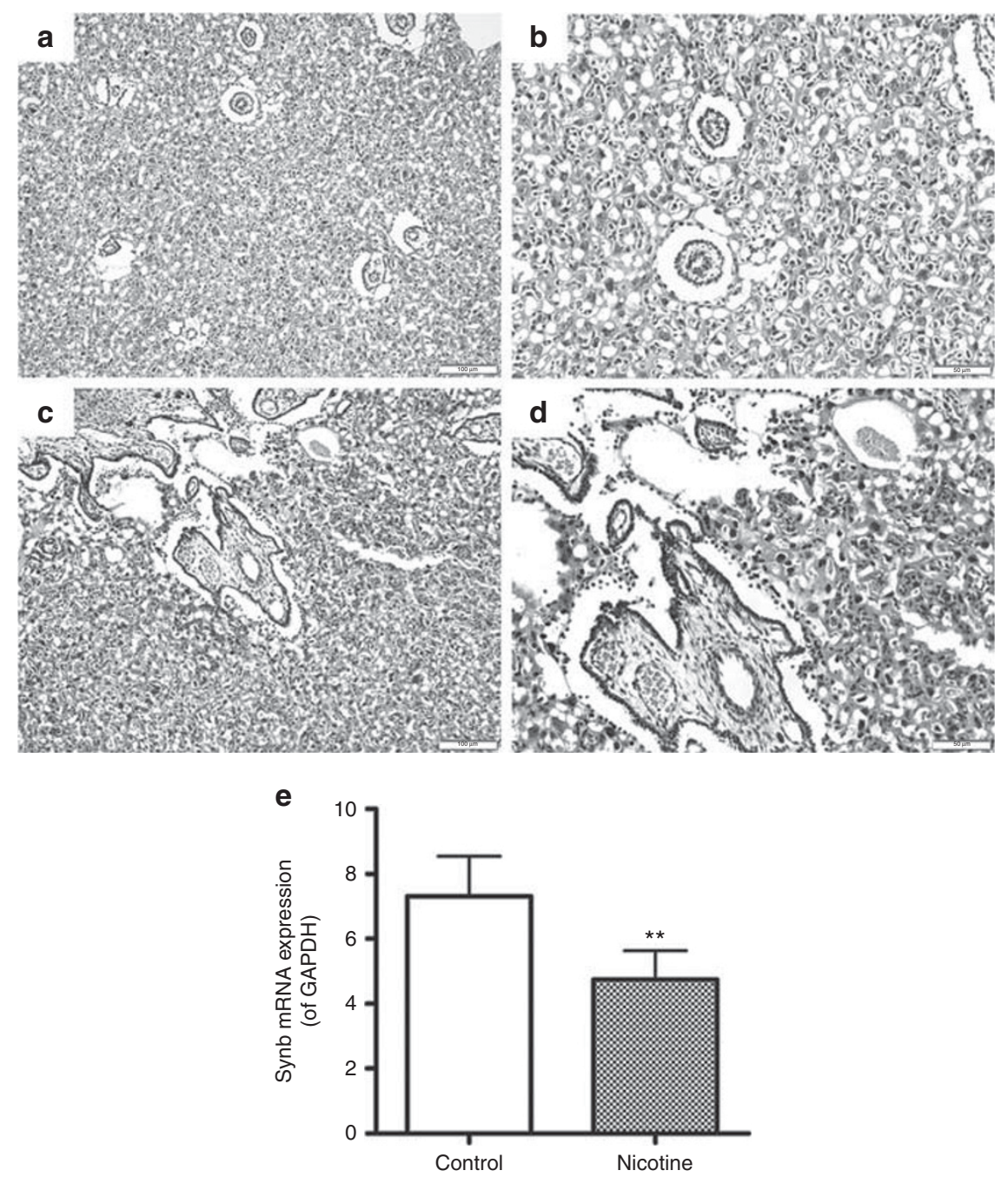

Figure 3. Histopathological changes and syncytin b (Synb) expression in placentae. Paraffin sections were stained with hematoxylin and eosin (HE) and observed under a light microscope. (a) Control ( $\times 100)$; (b) control $(\times 200)$; (c) nicotine $(\times 100)$; (d) nicotine ( $\times 20)$. (e) Real-time reverse-transcription PCR was used to verify the mRNA expression of Synb. Each sample was normalized on the basis of glyceraldehyde phosphate dehydrogenase $(G A P D H)$ mRNA content. Mean $\pm S D, n=8$ pregnant rats, ${ }^{* *} P<0.01$ vs. control.

epigenetic modification of nucleic acids, is more stable than RNA and more sensitive to environmental stimuli than DNA sequences $(7,25)$. Thus, DNA methylation patterns in maternal blood could be a promising method for prenatal IUGR screening.

Mammalian genomes contain a high frequency of $\mathrm{CpG}$ sites termed CpG islands. Most CpG islands are found in the proximal promoter regions of annotated genes in the mammalian genome. Methylation on the promoter $\mathrm{CpG}$ islands could result in chromatin remodeling and suppress gene expression (26). Thus, we used MeDIP array assays and the following GO analysis to evaluate the DNA methylation patterns of development-associated gene promoters in the maternal blood of IUGR rats. The results showed that the significantly changed DNA methylation frequencies were in genes involved in the development of multiple organs and major body systems, such as muscle and the nervous system.
It suggested that the occurrence of IUGR may be the result of the combined impact of the aberrant DNA methylation patterns of the whole fetus.

The placenta, an essential barrier for fetal development, is vulnerable to many adverse intrauterine factors (such as smoking). It has been reported that placental dysfunction is one of the predominant causes of IUGR $(22,27)$. We have found that prenatal exposure to some xenobiotics (such as caffeine, nicotine, and ethanol) could lead to placental dysfunction and cause fetal exposure to excessive maternal glucocorticoids in rats $(4,28,29)$. Excessive maternal glucocorticoid exposure has been reported to inhibit the development of multiple fetal organs or systems (such as skeletal growth, neuroendocrine system development) and induce IUGR in rats $(29,30)$. Thus, placental development may regulate fetal development by affecting the development of multiple fetal organs. In addition, placental dysfunction was 


\section{Articles | wu et al.}

reported to be related to the aberrant DNA methylation of genes regulating placental development (8). Thus, we intended to select a placenta-related gene for further confirmation.

\section{Hypermethylated Genes Regulating Placental Development in Maternal Blood of IUGR}

Among the genes regulating placental development, Synb, LRRC15, Met, and Tex19.1 showed significantly increased DNA methylation status. All of these four genes have an essential role in placental development, such as placental implantation and circulation. For example, LRRC15, which has a striking expression level within the cytotrophoblast cells of the placenta, has been reported to have an essential role during implantation (31). Ueno et al. demonstrated that loss of trophoblast $c$-Met could disrupt terminal differentiation and polarization of syncytiotrophoblasts, which could induce IUGR (32). According to the studies of Reichmann et al. (33), Tex $19.1^{-1-}$ mouse embryos exhibit intrauterine growth retardation and have small placentae due to a reduction in the number of spongiotrophoblast, glycogen trophoblast, and sinusoidal trophoblast giant cells. As the most significantly hypermethylated gene, Synb regulates the fusion and differentiation of trophoblast cells (34-37). It has been reported that increased DNA methylation of human syncytin promoter in placentae could inhibit its expression and induce placental dysfunction and IUGR (38). Thus, we chose the DNA methylation status of Synb in maternal peripheral blood to perform further verification.

BSP analysis demonstrated hypermethylated Synb in the maternal blood of IUGR rats, which is in line with the results of MeDIP array assays. In addition, decreased Synb expression and histological damages were shown in nicotine-treated placentae. It suggested that DNA hypermethylation of the Synb promoter in maternal peripheral blood could reflect placental dysfunction and the occurrence of IUGR in rats under prenatal nicotine exposure. Although no animal research has evaluated DNA methylation or expression of syncytin in placentae or maternal blood in IUGR models, decreased syncytin expression has been widely observed in human placentae and in the maternal blood of IUGR cases $(38,39)$. Moreover, Ruebner et al. (40) have demonstrated that reduced syncytin expression correlated with the corresponding epigenetic hypermethylation in human placentae with IUGR or preeclampsia. Consequently, we speculated that Synb hypermethylation may be associated with various IUGR models rather than be specific to nicotine.

\section{CONCLUSIONS}

In summary, our study showed the IUGR-associated DNA methylation profile in maternal blood, which provides evidence for further studies on possible IUGR biomarkers. For example, hypermethylated Synb in maternal blood could reflect placental dysfunction and the occurrence of IUGR. Our present study underlines the promise of DNA methylation status in maternal peripheral blood for IUGR screening and gives us a better understanding of IUGR pathophysiology. Further studies need to be carried out on Synb methylation confirmation in early gestation and other IUGR models.

\section{STATEMENT OF FINANCIAL SUPPORT}

This work was supported by grants from the National Natural Science Foundation of China (Nos. 81273107, 81673215, and 81173138) and the Outstanding Youth Science Fund of Hubei Province (No. 2012FFA017).

Disclosure: The authors declare no conflict of interest.

\section{REFERENCES}

1. Valsamakis G, Kanaka-Gantenbein C, Malamitsi-Puchner A, Mastorakos G. Causes of intrauterine growth restriction and the postnatal development of the metabolic syndrome. Ann N Y Acad Sci 2006;1092:138-47.

2. Imdad A, Yakoob MY, Siddiqui S, Bhutta ZA. Screening and triage of intrauterine growth restriction (IUGR) in general population and high risk pregnancies: a systematic review with a focus on reduction of IUGR related stillbirths. BMC Public Health 2011;11:S1.

3. Beltrand J, Lévy-Marchal C. Pathophysiology of insulin resistance in subjects born small for gestational age. Best Pract Res Clin Endocrinol Metab 2008;22:503-15.

4. Xu D, Liang G, Yan YE, et al. Nicotine-induced over-exposure to maternal glucocorticoid and activated glucocorticoid metabolism causes hypothalamic-pituitary-adrenal axis-associated neuroendocrine metabolic alterations in fetal rats. Toxicol Lett 2012;209:282-90.

5. Zhang L, Xu D, Zhang B, et al. Prenatal food restriction induces a hypothalamic-pituitary-adrenocortical axis-associated neuroendocrine metabolic programmed alteration in adult offspring rats. Arch Med Res 2013;44:335-45.

6. Klein G. Epigenetics: surveillance team against cancer. Nature 2005;434: 150.

7. Blair JD, Yuen RK, Lim BK, McFadden DE, von Dadelszen P, Robinson WP. Widespread DNA hypomethylation at gene enhancer regions in placentas associated with early-onset pre-eclampsia. Mol Hum Reprod 2013;19:697-708.

8. Reamon-Buettner SM, Buschmann J, Lewin G. Identifying placental epigenetic alterations in an intrauterine growth restriction (IUGR) rat model induced by gestational protein deficiency. Reprod Toxicol 2014;45: $117-24$.

9. Wu DM, He Z, Ma LP, Wang LL, Ping J, Wang H. Increased DNA methylation of scavenger receptor class B type I contributes to inhibitory effects of prenatal caffeine ingestion on cholesterol uptake and steroidogenesis in fetal adrenals. Toxicol Appl Pharmacol 2015;285: 89-97.

10. Ping J, Wang JF, Liu L, et al. Prenatal caffeine ingestion induces aberrant DNA methylation and histone acetylation of steroidogenic factor 1 and inhibits fetal adrenal steroidogenesis. Toxicology 2014;321:53-61.

11. Bamfo JE, Odibo AO. Diagnosis and management of fetal growth restriction. J Pregnancy 2011;2011:640715.

12. Chowdhury S, Erickson SW, MacLeod SL, et al. Maternal genome-wide DNA methylation patterns and congenital heart defects. PLoS ONE 2011;6:e16506.

13. Papageorgiou EA, Karagrigoriou A, Tsaliki E, Velissariou V, Carter NP, Patsalis PC. Fetal-specific DNA methylation ratio permits noninvasive prenatal diagnosis of trisomy 21. Nat Med 2011;17:510-3.

14. Kim MJ, Kim SY, Park SY, Ahn HK, Chung JH, Ryu HM. Association of fetal-derived hypermethylated RASSF1A concentration in placentamediated pregnancy complications. Placenta 2013;34:57-61.

15. Vidmar T, Freshwater L, Collins R. Understanding statistics in developmental and reproductive toxicology. In: Hood RD ed. Developmental and Reproductive Toxicology: A Practical Approach. New York, USA: Informa Healthcare, 2011: 542-62.

16. Engelbregt MJ, van Weissenbruch MM, Popp-Snijders C, Lips P, Delemarre-van de Waal HA. Body mass index, body composition, and leptin at onset of puberty in male and female rats after intrauterine 
growth retardation and after early postnatal food restriction. Pediatr Res 2001;50:474-8.

17. Delpisheh A, Brabin L, Drummond S, Brabin BJ. Prenatal smoking exposure and asymmetric fetal growth restriction. Ann Hum Biol 2008;35:573-83.

18. Gruslin A, Cesta CE, Bell M, Qing Q, Petre MA, Holloway AC. Effect of nicotine exposure during pregnancy and lactation on maternal, fetal, and postnatal rat IGF-II profile. Reprod Sci 2009;16:875-2.

19. Yildiz D. Nicotine, its metabolism and an overview of its biological effects. Toxicon 2004;43:619-32.

20. Holloway AC, Lim GE, Petrik JJ, Foster WG, Morrison KM, Gerstein HC. Fetal and neonatal exposure to nicotine in Wistar rats results in increased beta cell apoptosis at birth and postnatal endocrine and metabolic changes associated with type 2 diabetes. Diabetologia 2005;48:2661-6.

21. Lumley J, Oliver SS, Chamberlain C, Oakley L. Interventions for promoting smoking cessation during pregnancy. Cochrane Database Syst Rev 2004;4:CD001055.

22. Whitehead CL, Walker SP, Ye L, et al. Placental specific mRNA in the maternal circulation are globally dysregulated in pregnancies complicated by fetal growth restriction. J Clin Endocrinol Metab 2013;98:E429-36.

23. Pang WW, Tsui MH, Sahota D, et al. A strategy for identifying circulating placental RNA markers for fetal growth assessment. Prenat Diagn 2009;29:495-504.

24. Alberti A, Salomon LJ, Le Lorc'h M, et al. Non-invasive prenatal testing for trisomy 21 based on analysis of cell-free fetal DNA circulating in the maternal plasma. Prenat Diagn 2015;35:471-6.

25. Ivorra C, Fraga MF, Bayón GF, et al. DNA methylation patterns in newborns exposed to tobacco in utero. J Transl Med 2015;13:25.

26. Yaragatti M, Basilico C, Dailey L. Identification of active transcriptional regulatory modules by the functional assay of DNA from nucleosome-free regions. Genome Res 2008;18:930-8.

27. Leeuwerke M, Eilander MS, Pruis MG, et al. DNA methylation and expression patterns of selected genes in first-trimester placental tissue from pregnancies with small-for-gestational-age infants at birth. Biol Reprod 2016;94:37.

28. Liang G, Chen M, Pan XL, Zheng J, Wang H. Ethanol-induced inhibition of fetal hypothalamic-pituitary-adrenal axis due to prenatal overexposure to maternal glucocorticoid in mice. Exp Toxicol Pathol 2011;63:607-11.
29. Tan Y, Liu J, Deng Y, et al. Caffeine-induced fetal rat over-exposure to maternal glucocorticoid and histone methylation of liver IGF-1 might cause skeletal growth retardation. Toxicol Lett 2012;214:279-87.

30. Xu D, Zhang B, Liang G, et al. Caffeine-induced activated glucocorticoid metabolism in the hippocampus causes hypothalamic-pituitary-adrenal axis inhibition in fetal rats. PLoS ONE 2012;7:e44497.

31. Pollheimer J, Knöfler M. The role of the invasive, placental trophoblast in human pregnancy. Wien Med Wochenschr 2012;162:187-90.

32. Ueno M, Lee LK, Chhabra A, et al. c-Met-dependent multipotent labyrinth trophoblast progenitors establish placental exchange interface. Dev Cell 2013;27:373-86.

33. Reichmann J, Reddington JP, Best D, et al. The genome-defence gene Tex19.1 suppresses LINE-1 retrotransposons in the placenta and prevents intra-uterine growth retardation in mice. Hum Mol Genet 2013;22: 1791-806.

34. Black SG, Arnaud F, Palmarini M, Spencer TE. Endogenous retroviruses in trophoblast differentiation and placenta development. Am J Reprod Immunol 2010;64:255-64.

35. Dupressoir A, Lavialle C, Heidmann T. From ancestral infectious retroviruses to bona fide cellular genes: role of the captured syncytins in placentation. Placenta 2012;33:663-71.

36. Dupressoir A, Vernochet C, Bawa O, et al. Syncytin-A knockout mice demonstrate the critical role in placentation of a fusogenic, endogenous retrovirus-derived, envelope gene. Proc Natl Acad Sci USA 2009;106: 12127-32.

37. Mi S, Lee X, Li X, et al. Syncytin is a captive retroviral envelope protein involved in human placental morphogenesis. Nature 2000;403:785-9.

38. Ruebner M, Strissel PL, Langbein M, et al. Impaired cell fusion and differentiation in placentae from patients with intrauterine growth restriction correlate with reduced levels of HERV envelope genes. J Mol Med 2010;88:1143-56.

39. Whitehead CL, McNamara $\mathrm{H}$, Walker SP, et al. Identifying late-onset fetal growth restriction by measuring circulating placental RNA in the maternal blood at 28 weeks' gestation. Am J Obstet Gynecol 2016;214: e1-8.

40. Ruebner M, Strissel PL, Ekici AB, et al. Reduced syncytin-1 expression levels in placental syndromes correlates with epigenetic hypermethylation of the ERVW-1 promoter region. PLoS ONE 2013;8:e56145. 